\title{
Analysis of the Motion Response on the Cylindrical Platform of the Deep Sea
}

\author{
Achmad Baidowi ${ }^{1}$,Irfan Syarif Arief ${ }^{2}$, Ahmadi Munib $^{3}$
}

Received: 04 February 2019 / Revised: 18 March 2019 / Accepted: 19 March 2019

\begin{abstract}
Indonesia can be a solution to the energy crisis, and as the development of renewable energy. Several concepts of the floating marine current turbine (MCT) have been offered, one of them is the cylindrical platform. The object of the conducted study is $33 \mathbf{~ m}$ cylindrical platform with twin horizontal axis MCT installed underneath the platform. The analysis begins with the platform properties which include Centre of gravity, gyration radius and inertial. The environmental loads are $1 \mathrm{~m} / \mathrm{s}$ and $2 \mathrm{~m} / \mathrm{s}$ current speed, $2.4 \mathrm{~m}$ wave height, and $22 \mathrm{knots}$ wind. The properties will be used as input for motion analysis and mooring line tension. The results of the analysis with turret configuration of three lines and four lines show that the response amplitude operator (RAO) on the largest translational motion on surge motion as far as $4 \mathrm{~m}$ and rotational motion of 4.5 degrees. For the analysis of the mooring system the average maximum tension of the mooring chain reaches $2000 \mathrm{kN}$, with the maximum proof load at the value of $2245.82 \mathrm{kN}$ which resulted to a safety factor of 1,73 and it still complies to API RP 2SK Standard.
\end{abstract}

Keywords —Cylindrical Hull, Mooring System, Renewable Energy, Response Amplitude Operator, Tension

\section{INTRODUCTION}

About $80 \%$ of energy consumption currently provided by fossil fuels and the development of renewable energy in Indonesia is regulated in a Presidential Decree stating renewable energy must increase to $17 \%$ of total national primary energy in 2025 , with 5\% coming from hydropower. Every year Indonesia experiences a reduction in fossil-derived energy by $3 \%$ each year [1]. Studying marine energy potential can be a solution to building new types of power plants in Indonesia.

In 2018 the energy needs in Indonesia were approximately 1 billion $\mathrm{BOE}$ and will continue to increase every year [2].

Referring to the European Marine Energy Center Ltd. (EMEC) study, regarding non-renewable energy launched in 2013, it is developing ocean current energy with a potential of $2 \mathrm{MW}$. Environmental conditions in European countries, especially Scotland and the United Kingdom which have ocean currents with a speed between $3-5 \mathrm{~m} / \mathrm{s}$, are considered potential enough to be installed underwater turbines [3]. Whereas the temperature in the area is relatively small and is considered less good for the effect on the material.

Renewable energy sources are a new solution for meeting energy needs for the future[4]. When compared to Indonesia which has a current speed of between 1,5-3 $\mathrm{m} / \mathrm{s}$ and submarine temperatures compared to 25 degrees Celsius. Supporting areas for producing tidal energy generally at ocean currents of $1.5-3 \mathrm{~m} / \mathrm{s}$ (not affected by

Achmad Baidowi, Department of Marine Engineering, Institut Teknologi Sepuluh Nopember, Surabaya 60111, Indonesia, Email: ahmadbai@gmail.com

Irfan Syarif Arief, Department of Marine Engineering, Institut Teknologi Sepuluh Nopember, Surabaya 60111, Indonesia, Email: irfansya@its.ac.id

Ahmadi Munib, Department of Marine Engineering, Institut Teknologi Sepuluh Nopember, Surabaya 60111, Indonesia, Email: ahmd.munib@gmail.com annual weather) have a wave height of no more than 8 meters and the wave period does not exceed 2 times the length of the platform. In the following paper the author uses the environmental area in the Toyopakeh Strait, Nusa Penida-Bali to be used as an input environment.

A. Floating Structure

Several types of foating structures for ocean current turbine in deep water have been proposed. One of them is quadrimaran platform for vertical axis turbine [5]. And cylindrical platform which offered by Scotrenewables Tidal Power [6] and some of the concept are using a submerged platform such as sabella turbine and OpenCentre Turbine[7].

B. Wave Spectrum-JONSWAP

The JONSWAP spectrum is based on experiments conducted in the North Sea. The wave spectrum used in this analysis refers to the JONSWAP wave spectrum because the characteristics of Indonesian waters are closed so that they match the JONSWAP spectrum character. This condition is reinforced that the JONSWAP wave spectrum presentation model has more information about spectrum for various sea conditions. In actual conditions, the ocean spectrum is more peaked than the spectrum of fully developed seas. After reanalyzing the data from Pierson and Moskowitz, Hasselmann et al. observed that more than half of the spectrum contains many peaks, in other words, two or more peaks are equipped with a single function, which can result in improper functions. Excluding some of these peak results, it is observed that the peak increase factor must be $\gamma=1.4$ for the fully developed sea, not $\gamma=1[8]$.

The JONSWAP spectrum equation can be written by modifying the Pierson-Moskowitz spectrum equation [9], is:

$$
\begin{aligned}
& S(\omega)=\alpha g^{2} \omega^{-5} \exp \left[-\frac{5}{4}\left(\frac{\omega}{\omega p}\right)^{4}\right] \\
& \delta=\exp \left[-\frac{(\omega-\omega \mathrm{p})^{2}}{2 \sigma^{2} \omega p^{2}}\right]
\end{aligned}
$$




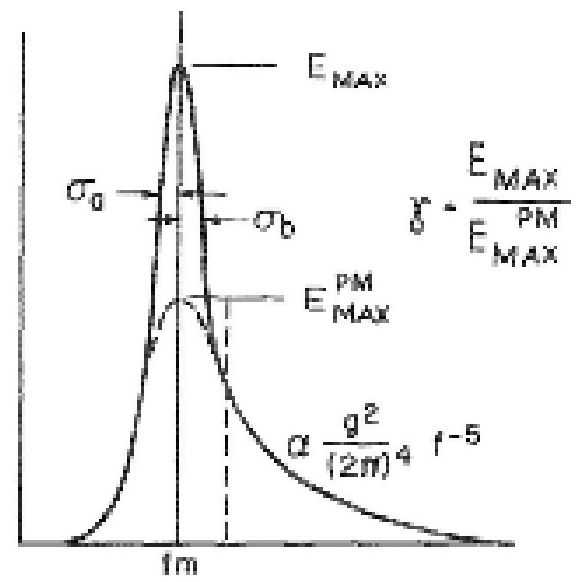

Figure 1. Comparison of the spectrum of Jonswap waves (high peaks) with Pierson Markowitz

Or use the following equation, by entering the wave frequency parameter repeatedly into the Pierson Markowitz equation

$$
\operatorname{Sj}(\omega) \quad=\mathrm{A}_{\gamma} \mathrm{S}_{\mathrm{pm}}(\omega) \gamma^{\exp }\left[\frac{\omega \omega p}{\sigma \omega p}\right]
$$

With, Spm = Spectra of Pierson-Markowitz

$$
\begin{gathered}
=\frac{5}{\mathrm{~s}} H s^{2} \omega p^{2} \omega^{-5} \exp \left[-\frac{5}{4}\left(\frac{\omega}{\omega n}\right)^{-4}\right] \\
\gamma \quad=\text { peakedness parameter } \\
\sigma \quad=\text { shape parameter for } \omega \leq \omega_{0} \\
\quad=0,07 \text { dan } \omega \leq \omega_{0}=0,09
\end{gathered}
$$

\section{Environmental Factor}

Conformity of conditions that are close to real on site for structural response analysis, non-linear factors must be considered in calculations. The area that has the influence of the style and moment of the cycle of curing, according to the rules of OCIMF:

$$
\begin{array}{ll}
\text { A surge } & =\mathrm{L} . \mathrm{D} \\
\text { A sway } & =\mathrm{L} . \mathrm{D} \\
\text { A yaw } & =\mathrm{L}^{2} \mathrm{D}
\end{array}
$$

Wind load is calculated based on the amount of extreme speed with a 100 year return period. The longer the return period is used, the greater the risk of failure[9].

Based on OCIMF of mooring equipment guidelines, the calculation of wind loads is defined :

- Wind Drag Load

$$
\begin{aligned}
& \mathrm{F}_{\mathrm{x}}=\frac{1}{2} \boldsymbol{\rho}|\boldsymbol{\omega}| \boldsymbol{\omega} . \mathrm{K} \text { surge } \\
& \mathrm{F}_{\mathrm{y}}=\frac{1}{2} \boldsymbol{\rho}|\boldsymbol{\omega}| \boldsymbol{\omega} . \mathrm{K} \text { sway } \\
& \mathrm{m}_{\mathrm{Z}}=\frac{1}{2} \boldsymbol{\rho}|\boldsymbol{\omega}| \boldsymbol{\omega} . \mathrm{K} \text { yaw }
\end{aligned}
$$

- Drag load pada relative velocity

$$
\begin{aligned}
& \mathrm{F}_{\mathrm{x}}=\frac{1}{2} \text { Csurge } \rho|\vartheta|^{2} \text { A surge } \\
& \mathrm{F}_{\mathrm{y}}=\frac{1}{2} \text { Csway } \rho|\vartheta|^{2} \text { A sway } \\
& \mathrm{m}_{\mathrm{x}}=\frac{1}{2} \text { Cyaw } \rho|\vartheta|^{2} \text { A yaw }
\end{aligned}
$$

$$
\begin{array}{ll}
\boldsymbol{\rho} & =\text { air density } \\
\omega & =\text { yaw rate platform }(\mathrm{rad} / \mathrm{s})
\end{array}
$$

$\mathrm{K}$ surge, $\mathrm{K}$ sway and $\mathrm{K}$ yaw = factor yaw drag rates at the load of the current passing through the ship $\mathrm{fx}$, fx, and $\mathrm{mz}=$ drag styles on $\mathrm{x}$ - and $\mathrm{y}$-direction moments

Csurge, Csway, $\mathrm{Cw}=$ current or wind coefficient

The time series wave force can be generated from the wave spectrum as First Order and Second Order. First Order is a wave with a small period whose generating area is in the area itself and has a dominant influence on the movement of floating buildings. The following is the first order wave force equation.

$$
F_{W V}^{(1)}(t)=\sum_{i=1}^{N} F_{W V}^{(1)}\left(\omega_{i}\right) \cos \left(\omega_{i}+c_{i}\right) \alpha_{i}
$$

Where :

$\mathrm{F}_{\mathrm{wv}}{ }^{(1)}(\mathrm{t}) \quad=$ wave force in first order at time function

$\mathrm{F}_{\mathrm{wv}}{ }^{(1)}(\mathrm{w})=$ exciting wave force first order per unit of wave amplitude

$$
\begin{array}{ll}
\epsilon_{\mathrm{i}} & =\text { wave phase angle in first order } \\
\alpha_{\mathrm{i}} & =\text { amplitude-wave component in first order }
\end{array}
$$

Second Order is a high-period wave whose generating area is not in the area (far from the wave location).

Following is the equation of the Second Order wave style.

$$
\begin{array}{r}
F_{w v}^{(z)}(t)-\sum_{i=1}^{v} \Sigma_{j=1}^{N} \alpha_{c} \alpha_{j} D_{j j} \cos \left[\left(\omega_{i}-\omega_{j}\right) t+\left(\varepsilon_{i}-\varepsilon_{j}\right)\right] \\
D_{\mathrm{ij}} \quad=\text { Drift force per unit wave amplitude }
\end{array}
$$

While currents caused by wind have the same character, but in linear functions. The Mooring Equipment Guidelines, current load calculations are defined as follows [10]:

- Longitudinal current force

- Lateral current force

The forces on the current passing through the platform are:

Where: 


$$
\begin{aligned}
& \mathrm{F}_{1}=\frac{1}{2} C 1 \rho V c^{2} \\
& \mathrm{~F}_{\mathrm{d}}=\frac{1}{2} C d \rho V c^{2} A
\end{aligned}
$$

$$
\begin{aligned}
& \text { Where: } \\
& \mathrm{F}_{1}=\text { lift force }(\mathrm{N}) \\
& \mathrm{F}_{\mathrm{d}}=\text { drag force }(\mathrm{N}) \\
& \mathrm{C}_{1}=\text { lift coefficient } \\
& \mathrm{C}_{\mathrm{d}}=\text { drag coefficient } \\
& \boldsymbol{\rho}=\text { density of water }\left(\mathrm{kg} / \mathrm{m}^{3}\right) \\
& \mathrm{A}=\text { area reviewed }\left(\mathrm{m}^{2}\right) \\
& \mathrm{V}_{\mathrm{c}}=\text { current velocity }\left(\mathrm{m} / \mathrm{s}^{2}\right)
\end{aligned}
$$

\section{Response Amplitude Operators (RAO)}

It is an integrated dynamic response analysis carried out to study how far aerodynamic and hydrodynamic, and dynamic structures in extreme environments/consideration of the presence of induced waves and wind generated [11]. The response of the translation motion (surge - sway - heave) is a comparison between the amplitude of motion compared to the amplitude of incidental waves. While the response of the rotational motion (roll - pitch - yaw) is a comparison between the amplitude of the rotational movement of the radians) with the slope of the wave $\left(\mathrm{kw}=\omega^{2} / \mathrm{g}\right)$.

$$
\text { RAO }(\omega)=\frac{X p(\omega)}{\eta(\omega)}
$$

Where :

$\mathrm{Xp}(\omega)=$ structure amplitude $(\mathrm{m})$

$\eta(\omega)=$ wave amplitude $(\mathrm{m})$

RAO equation for translation above. As for the RAO movement response for rotational motion (roll, pitch, yaw) is the ratio between the amplitude of the rotational motion (in radians) and the slope of the wave, which is the multiplication of waves $(\mathrm{kw}=\omega 2 / \mathrm{g})$ with the incident wave amplitude [12].

The radius of gyration, is the length or distance between the turning points of an object and the point of energy transfer originates. In a system with a moment of inertia the relationship is both :

$$
\mathrm{K}^{2}=\mathrm{I} / \mathrm{m}
$$

$$
\begin{array}{ll}
\text { Where: } & \\
\text { K } & =\text { Radius of gyration } \\
\text { I } & =\text { Moment of Inertia } \\
\text { M } & =\text { mass }
\end{array}
$$

\section{E. Wave Theory}

- Regular wave (linear airwave)

It is assumed that the wave conditions in the sea are flat and do not have a limit on the surface until the value is infinite. This condition is most often applied to calculate wave loads that occur in structures [13]. The given wave period is assumed to be a constant variable that does not change.

\section{- Irregular Wave}

Namely the movement of floating buildings in the sinusoidal wave excitation reaction, with high characteristics or amplitude and a certain frequency (may change at any time). In some analysis methods, conditioned wave amplitude is constant, but the frequency is varied with certain internal increases. Irregular waves are superpositions due to the shape of objects and their constituent components which form an infinite sinusoidal wave, this is because each component or each shape has a certain energy level that is contributed, the results is formalized in the form of a wave energy spectrum [14].

\section{F. Mooring System}

The Turret Mooring System (TMS) mooring system is one mooring system utilizing a single point to become a rope connection with an offshore platform to enable handling of mooring systems on ships affected by high currents and waves. In addition, the general mooring system is a link between a barge or a ship with coastal facilities and is used for distribution from the rig to the tanker.

\section{G. Calculation of mooring systems}

Calculation of rope length/mooring chain will affect the position of the rope at a certain bathymetry height. In pairs, mooring lines can be tense, during low tide the mooring can experience estrangement

The equation determines the minimum length of the mooring rope.

$$
\frac{l}{h}=\sqrt{\frac{2 F_{H}^{2}}{P h}}+1
$$

$$
\begin{aligned}
& \text { Where: } \\
& \mathrm{l}=\text { minimum length of chain line. } \\
& \mathrm{h}=\text { water depth. } \\
& \mathrm{Hc}=\text { fairlead height above the water surface. } \\
& \mathrm{P}=\text { chain line weight in long united water. } \\
& \mathrm{Fh}=\text { horizontal chain line style on fairlead. } \\
& \mathrm{t}=\text { the tension of the chain line on fairlead. } \\
& \mathrm{d}=\text { length resting on the seabed }
\end{aligned}
$$

\section{H. Maximum Tension}

Is the maximum tensile force that is affected by a combination of wave frequency and low-frequency tension. Maximum tension calculation according to Faltinsen (1990) can use the equation:

$\operatorname{Tmax}=\mathrm{Th}+\mathrm{wh}$

Where :

Tmax $=$ maximum rope tension (ton)

$\mathrm{Th}=$ horizontal pre-tension (tons)

$\mathrm{w}=$ chain weight in water $(\mathrm{ton} / \mathrm{m})$

$\mathrm{h} \quad=$ water depth $(\mathrm{m})$

\section{Safety Factor}

The safety factor value on the mooring line must be based on checking the rope strength structure first. The maximum tensile force must be adjusted to the criteria or limits that meet the standard safety factor [15]. 
TABLE 1

SAFETY FACTOR STANDART API RP 2SK (2005), MOORING SYSTEM

\begin{tabular}{cc}
\hline Condition & Safety Factor \\
\hline Intact (ULS) & $>1.67$ \\
Damaged (ALS) & $>1.25$ \\
\hline
\end{tabular}

The equation for the safety factor according to API

RP 2SK :

\section{A. Research Data}

Safety factor $=\frac{\text { minimum Breakingloads }}{\text { Maximum Tension }}$

The cylindrical hull structure is held by 1 mooring with mooring which is later transferred using a chain to seabed area to reduce waves caused by ocean waves.

TABLE 2 .

PRINCIPAL DIMENSION OF PONTOON

\begin{tabular}{ll}
\hline Main Dimension & Unit \\
\hline Length of Platform (LOA) & $33,665 \mathrm{~m}$ \\
Maximum diameter (B) & $2,325 \mathrm{~m}$ \\
Draught & $1,1625 \mathrm{~m}$ \\
Length of leg & $9,597 \mathrm{~m}$ \\
Blade diameter of the turbine & $8 \mathrm{~m}$ \\
Distance of turbines & $12,338 \mathrm{~m}$ \\
\hline
\end{tabular}
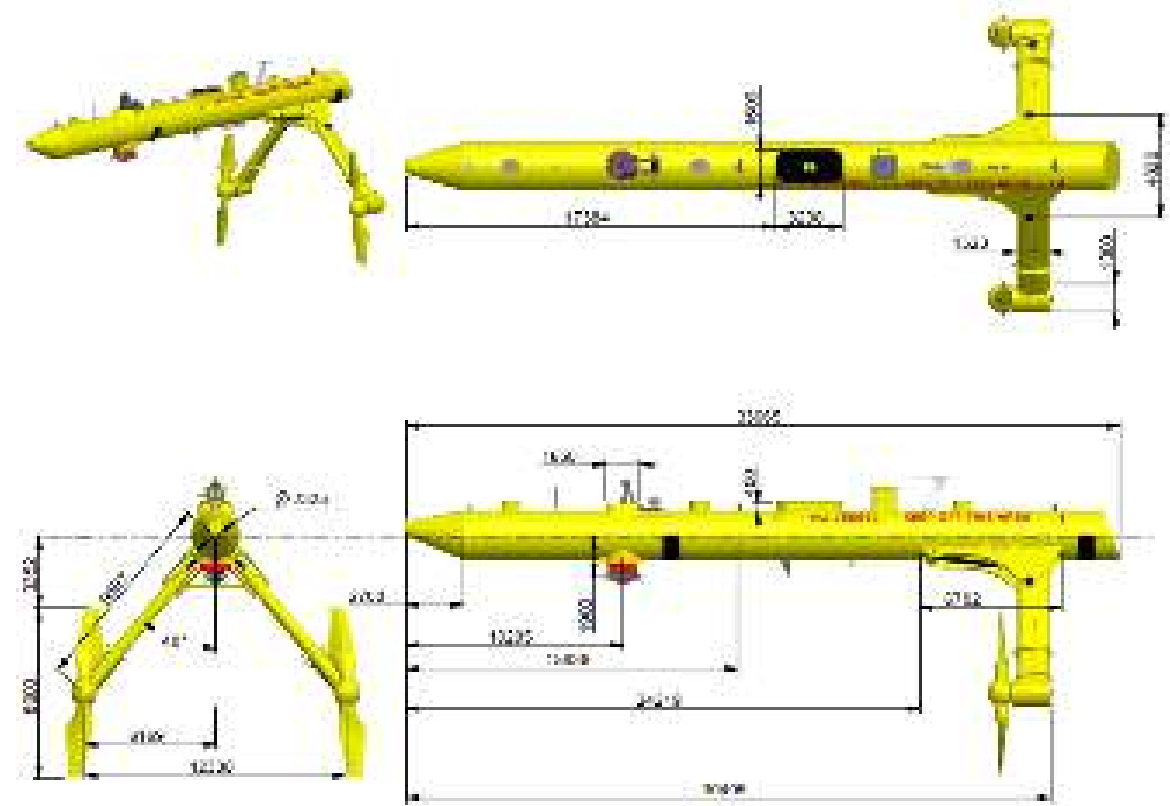

Figure 2. Platform Model

\section{B. Environmental Data}

The following environmental data uses actual data in the field as found in actual conditions. Wind speed data at the coordinate position of data retrieval is located in Nusa Penida waters in the Toyapakeh

strait, namely $8^{\circ} 63^{\prime} 79.70$ "LS and $115^{\circ} 49^{\prime} 91.47^{\prime \prime}$ BT for the north of Nusa Penida Island, and $8^{\circ}$ $72^{\prime} 84.30$ "LS and $115^{\circ} 42^{\prime} 83.54$ "BT for the south of Nusa Penida Island.

TABLE 3.

WAVE HEIGHT ON THE TOYAPAKEH STRAIT OF NUSA PENIDA - BALI

\begin{tabular}{ccc}
\hline Wind direction & Significant wave height $(\mathbf{m})$ & Significant wave period (s) \\
\hline West & 0.9 & 3.77 \\
Northwest & 1.58 & 4.85 \\
East & 2.4 & 5.93 \\
\hline
\end{tabular}


TABLE 3.

ENVIRONMENTAL DATA AT MAXIMUM CONDITIONS

\begin{tabular}{cccc}
\hline Sig Wave Height & Wind speed & Current & Water Depth \\
\hline $2.4 \mathrm{~m}$ & $22 \mathrm{knot}$ & $2.4 \mathrm{~m} / \mathrm{s}$ & $100 \mathrm{~m}$ \\
\hline
\end{tabular}

TABLE 4.

SIGNIFICANT WAVE HEIGHT IN EACH DIRECTION OF THE WIND

\begin{tabular}{lllll} 
Year & 10 & 25 & 50 & 100 \\
Hs & 0.74 & 0.97 & 1.14 & 1.32 \\
\hline
\end{tabular}

C. Design with Maxsurf Modeller

From the design in maxsurf, the hydrostatic

value is calculated which works on the platform.

TABLE 5.

MAXSURF'S HYDRODYNAMIC RESULT

\begin{tabular}{llll}
\multicolumn{4}{c}{ MAXSURF'S HYDRODYNAMIC RESULT } \\
\hline No & \multicolumn{1}{c}{ Name } & Value & Unit \\
\hline 1 & Displacement & 71,639 & $\mathrm{t}$ \\
2 & Volume (displaced) & 69,891 & $\mathrm{~m}^{3}$ \\
3 & Draft amidships & 1,163 & $\mathrm{~m}$ \\
4 & WL Length & 33,677 & $\mathrm{~m}$ \\
5 & Beam max extents on WL & 2,325 & $\mathrm{~m}$ \\
6 & Wetted Surface Area & 120,869 & $\mathrm{~m}$ \\
7 & Max sect. area & 2,195 & $\mathrm{~m}^{2}$ \\
\hline
\end{tabular}

After knowing the hydrostatic value above, then the model needs to be meshed to then be inserted into Moses Motion. In this case, the platform is known as seakeeping under regular wave conditions

\section{Solidwork modeling}

Using Solidwork software is used to find out the value:

1) The total mass of the platform

2) Total platform volume

3) Momeen Inertia

\section{4) Center of Gravity}

\section{E. Design in MOSES Software}

The motion calculation is conducted in free-floating conditions. Mooring is modeled and simulated according to existing data. The environmental load is considered in collinear direction which means the direction of wave, current, and wind is in the same direction.

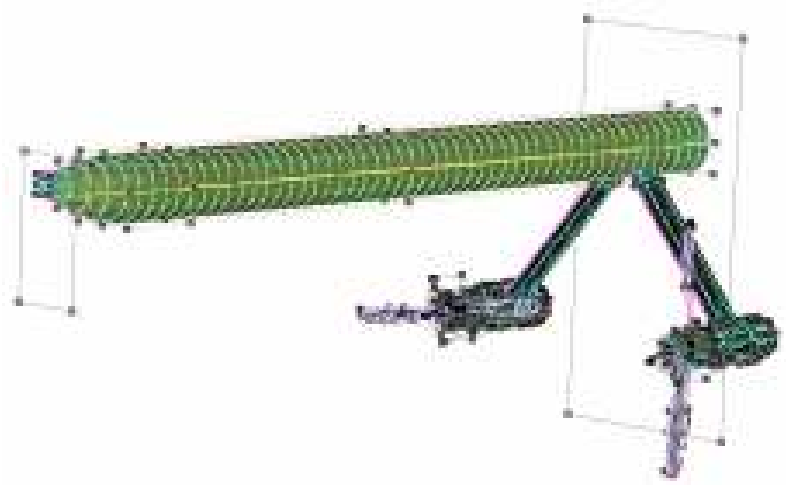

Figure 3. Platform Model on MOSES Software

\section{F. Analysis of Mooring Line Tension}

The next analysis is to determine the maximum tension that occurs on the mooring line as a result of structural response parameters, mooring tension, excursion, and line clashing. At this stage the tension value from the results of the simulated variations are analyzed and compared with the API RP 2SK Standard, namely the maximum tension and maximum breaking load. 


\section{RESULTS AND DISCUSSION}

Analysis of motion response behavior from the platform in a free-floating condition at regular wave conditions. The results of the MOSES software analysis in the form of response to the movement of the platform in the condition of 6 degrees of freedom (RAO). The RAO value is then described in the movement of six degrees of freedom (surge, sway, heave, roll, pitch and yaw). The RAO transfer function graph is presented with abscissa ( $\mathrm{x}$-axis) in the form of wave frequency and $\mathrm{y}$ axis in the form of RAO values for translational motion with units $(\mathrm{m} / \mathrm{m})$ and for rotational movements with units (deg/m).

\section{A. Analysis of the surge motion}

Motion movements of surge in all loading directions have almost the same character. The greatest value of sway motion on the ship reaches $4.2 \mathrm{~m} / \mathrm{m}$ at a frequency of $0.2 \mathrm{rad} / \mathrm{s}$. Increasing wave frequency makes the response received by the ship smaller (the damping value gets bigger). Shows the ship's response at a frequency interval of $1 \mathrm{rad} / \mathrm{s}$, which further reduces the response of the ship's motion to close to 0 , meaning that the ship will not be affected by environmental conditions (waves and wind) at large frequencies.

\section{B. Sway motion analysis}

Sway movement response has almost the same character in each direction of loading. The response value is slightly constant at frequencies of more than 0.5 $\mathrm{rad} / \mathrm{s}$, except at frequencies of $0.25 \mathrm{rad} / \mathrm{s}$ to $0.5 \mathrm{rad} / \mathrm{s}$ the largest ship response value at a distance of $1.2 \mathrm{~m} / \mathrm{m}$ which approaches the value of half the width of the ship. This will tend to decrease until it approaches the value of 0 at an increasingly large frequency. The value of damping and added mass of sway motion can reduce the response received by the ship's body.

\section{Heave motion analysis}

Heave motion is a vertical movement of the ship's body. Measurement of the amplitude response based on how far the floating building is at the condition of receiving loads at certain angles calculated when the water conditions are calm. The graph above shows if the movement of floating buildings tends to change up and down (dynamic). The response of ship movements at low frequencies has the greatest value reaching $0.65 \mathrm{~m} / \mathrm{m}$ and moves significantly lower (moving up at a distance of $0.6 \mathrm{~m}$ and down to a distance of $0.1 \mathrm{~m} / \mathrm{m}$ before then rising again). The RAO value along the wave frequency is constant (close to $0 \mathrm{~m}$ ) in the direction of the frequency above $1.5 \mathrm{rad} / \mathrm{s}$.

\section{Analysis of roll motion}

The rolling movement is a rotational movement received by floating buildings due to outside influences. The graph above shows if the ship's roll movement or in this case a cylindrical floating building tends to be random (up and down), experiencing the highest increase in the wave frequency interval of $0.4 \mathrm{rad} / \mathrm{s}$ for the largest loading direction at $0^{\circ}$ and $180^{\circ}$. The highest amplitude response value occurs at a frequency of 0.4 to $0.5 \mathrm{rad} / \mathrm{s}$ with a slope of $2.4 \mathrm{deg} / \mathrm{s}$. The motion response in all loading directions in the largest position at the beginning and experiencing a reduction in value is close to 0 even though a moment later rises and falls to a constant value. The response looks down after being at an amplitude value above $1.5 \mathrm{rad} / \mathrm{s}$ in all five loading directions.

\section{E. Analysis of pitch motion}

In the motion chart Pitch can be seen if the response value of floating buildings in the pitch motion has a value close to the same. The biggest response is received at a frequency of $0.5 \mathrm{rad} / \mathrm{s}$ which is worth 4.5 degrees in all directions of loading. The movement response tends to decrease significantly at $1 \mathrm{deg} / \mathrm{s}$ before being constant at frequencies above $2 \mathrm{rad} / \mathrm{s}$. This means that the floating building response value is not greater than $5 \mathrm{deg} / \mathrm{s}$ under environmental conditions and will approach stable at a response value of less than $1 \mathrm{deg} / \mathrm{s}$.

\section{F. Analysis of yaw motion}

In the Yaw motion graph shows at the beginning of the loading frequency wave has the highest motion response value at $3.5 \mathrm{deg} / \mathrm{s}$. The greatest amplitude response value is in the direction of load 0-degrees with a value reaching $3.5 \mathrm{deg} / \mathrm{m}$, and for the load direction 180 degrees reaches the highest point at a frequency interval of $0.4 \mathrm{rad} / \mathrm{s}$ with an amplitude response value of 3.3 degree/s, such as the high frequency of the received wave, the response of the received yaw motion continues to fall until it reaches a stable condition at an amplitude of $0.1-0.4 \mathrm{deg} / \mathrm{m}$. This condition means that loading which has a value of 0 has no effect on the yaw movement of the hull.

The next analysis is the magnitude of the rope tension distribution on the connection platform and seabed. This aims to determine the chain selection for the mooring system according to the maximum stress that occurs.

1) Analysis of tension on the mooring system (3 Line; Current $1 \mathrm{~m} / \mathrm{s}$ )

On the graph of the End A voltage (3 Line; Current 1 $\mathrm{m} / \mathrm{s}$ ) above is shown the value of the mooring system voltage at the end of the rope connected to the platform (End A). The largest value of rope tension is when the platform accepts loading in the direction of 0 degrees which is equal to $2607,664 \mathrm{kN}$ on Line 1 . The lowest value is received in the direction of 45 degrees load on Line 2 of $43.75 \mathrm{kN}$. The graph shows the load distribution for each mooring chain in actual conditions, with a current velocity of $1 \mathrm{~m} / \mathrm{s}$. The platform position will adjust to the position parallel to the arrival of the current because it uses a turret mooring system type mooring system.

On the End B graph (3 Line; Current $1 \mathrm{~m} / \mathrm{s}$ ) is shown the value of the mooring system at the end of the rope connected to the seabed (End B). The largest value of rope tension is when the platform receives loading in the direction of 0 degrees which is equal to $2595.76 \mathrm{kN}$ on Line 1 . The lowest value is received in the direction of 
loading 45 degrees on Line 2 of $30.25 \mathrm{kN}$. The difference in tension on the rope is caused by differences in the effect of loading direction with the fixed angle between the moorings. If the value of the mooring rope has a small value, it is likely that the rope/mooring chain will experience an excursion.

2) Analysis of tension on the mooring system (4 Line; Current $1 \mathrm{~m} / \mathrm{s}$ )

Load distribution in the End A data above uses 4 chains with each chain length of $150 \mathrm{~m}$, and the angle between the chains is 90 degrees. End A graph shows the stress distribution on each rope with a current value of 1 $\mathrm{m} / \mathrm{s}$. The largest rope tension conditions are on the 4 th rope and when the loading direction is 135 degrees from the forepeak. The smallest voltage value is on the 3rd rope when the direction of loading is 45 degrees.

The End B graph shows the stress distribution in the chain connected on the seabed. The largest voltage value is on the 4th rope and when the loading direction is 135 degrees which is equal to $879.76 \mathrm{kN}$. The value of the lowest voltage on the 3rd chain and when the loading direction is 45 degrees which is equal to $312.16 \mathrm{kN}$. The loading value on 4 lines is not as big as 3 lines which reaches more than $2000 \mathrm{kN}$ in almost all directions of loading. The loading value drops relatively when adding the number of mooring chains.

3) Analysis of tension on the mooring system (4 Line; Current $2 \mathrm{~m} / \mathrm{s}$ )

End A graph shows the load distribution at the time of the 4 Line mooring design with a current strength of 2 $\mathrm{m} / \mathrm{s}$. The rope tension value in all loading directions has a maximum index of more than $2000 \mathrm{kN}$. The value of the largest mooring tension is found on the 4th rope when receiving the loading direction of 135 degrees which is equal to $2245.82 \mathrm{kN}$. The smallest rope voltage value in the 4 th chain with a 0 degree loading direction of $213.99 \mathrm{kN}$.

The load distribution on the rope or chain has a value that is not much different than the connection to the platform (End A). The biggest value of rope tension is in the 4th chain in the direction of loading 135 degrees. While the lowest value occurs in the third chain when the direction of loading is 0 degrees. Please note the maximum voltage value in each direction of loading is below $2300 \mathrm{kN}$. The value of this maximum voltage are used as a reference for the selection of the rope/anchor chain according to the proof load and maximum breaking load (MBL).

The distribution of loads on each rope/chain has a significant difference. In this case, the selection of the rope/chain is adjusted to the value of the proof load of the rope/chain at the maximum stress. The next step is the selection of string/mooring specifications that correspond to the proof load chain value with a value of not less than $2500 \mathrm{kN}$ and the rope/chain mass approaches the assumption used in the output files of MOSES Ultramarine software.

\section{Selection of the Chain Strap on the Mooring System}

In selecting the chain on this mooring system the author uses the following specifications:

$\begin{array}{ll}\text { Type } & : \text { Studlink Chain } \\ \text { Grade } & : 4 \\ \text { Diameter } & : 54 \mathrm{~mm} \\ \text { Proof Load } & : 2500 \mathrm{kN}\end{array}$

Maximum Breaking Load : $3180 \mathrm{kN}$

Appox. Mass $\quad: 65 \mathrm{~kg} /$ meter

The calculation of the safety factor is calculated based on the breaking load value of the maximum state compared to the maximum voltage exposed to the chain.

The safety factor equation according to API RP 2SK are:

$\begin{aligned} \text { Safety factor } & =\frac{\text { minimum Brøaking loads }}{\text { Maximum Tension }} \\ \text { Safety factor } & =\frac{3970}{2245.82}(\mathrm{kN}) \\ & =1.73\end{aligned}$

TABLE 6.

SAFETY FACTOR BASED ON API RP2SK

\begin{tabular}{cc}
\hline Condition & Safety Factor \\
\hline Intact (ULS) & $>1.67$ \\
\hline Damaged (ALS) & $>1.25$
\end{tabular}

TABLE 7.

CHAIN TENSION

\begin{tabular}{ccc} 
& CHAIN TENSION \\
\hline Parameters & $\begin{array}{c}\text { Maximum Tension } \\
(\boldsymbol{k} \boldsymbol{N})\end{array}$ & $\begin{array}{c}\text { Proof Load } \\
(\boldsymbol{k} \boldsymbol{N})\end{array}$ \\
\hline On Chain & 2245,82 & - \\
\hline On Chain Specification & 3870 & 3040 \\
\hline
\end{tabular}




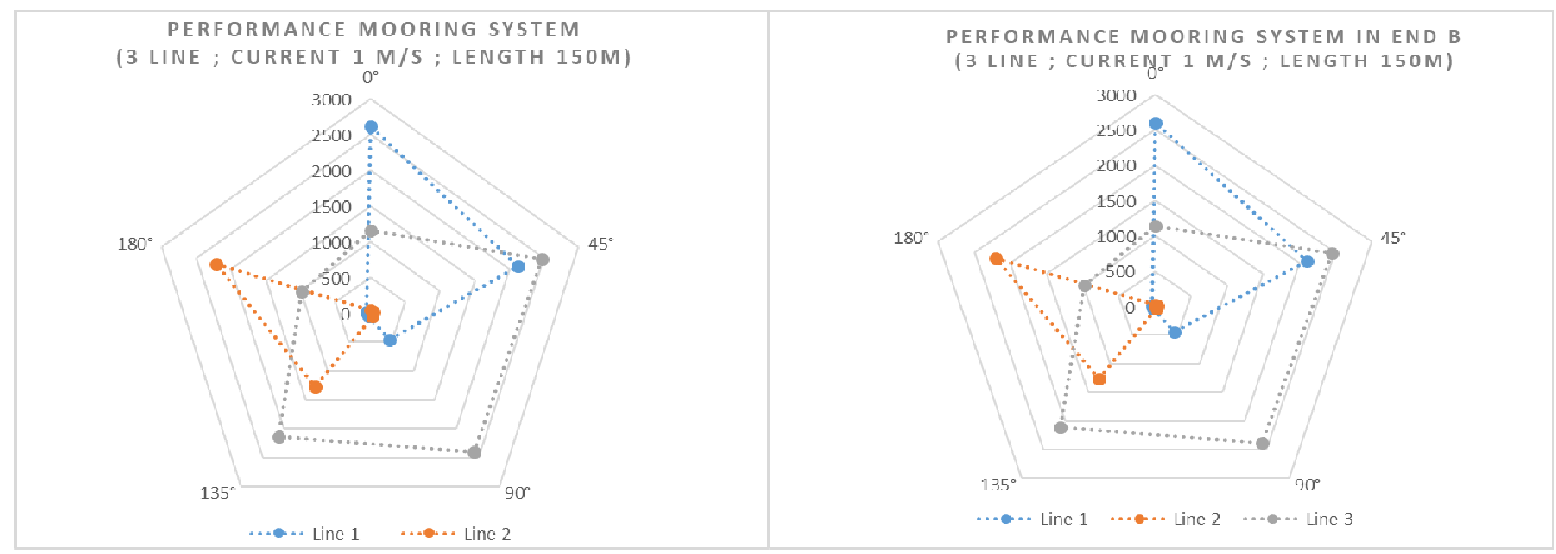

Figure 4. Distribution of mooring chain tension on the platform (End A) and seabed (End B) (3 Line; Current $1 \mathrm{~m} / \mathrm{s}$ )

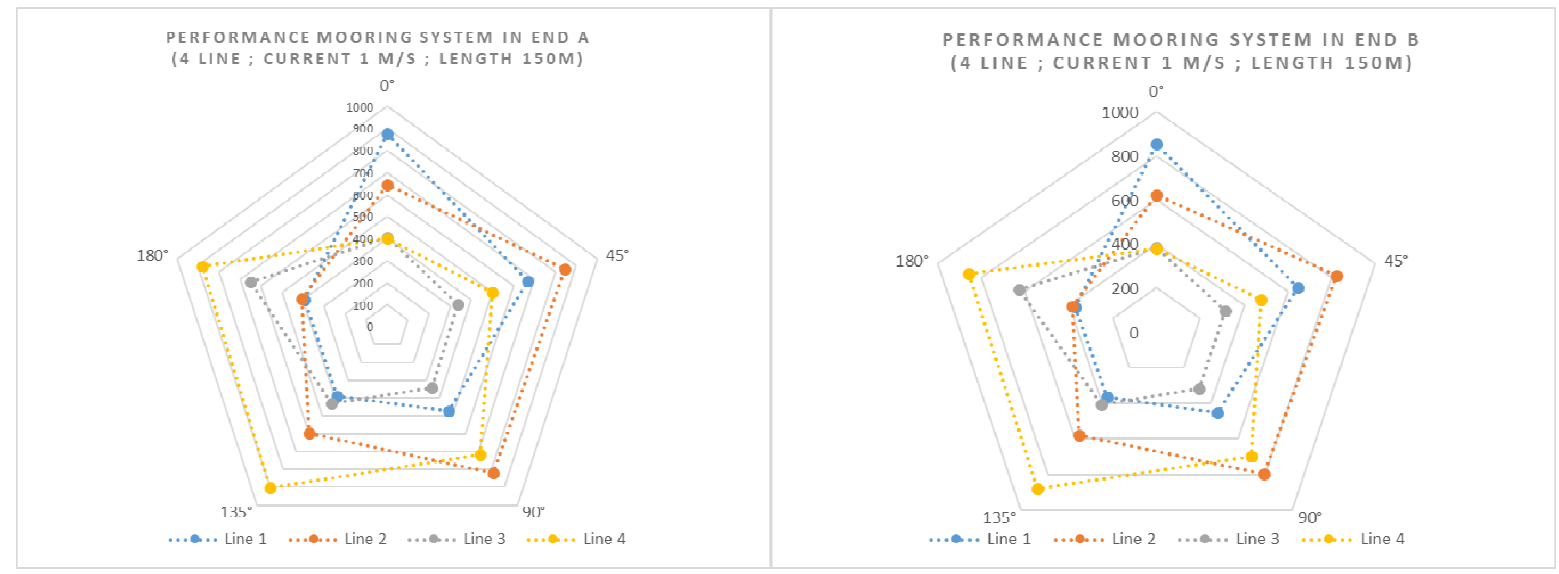

Figure 5. Distribution of mooring chain tension on the platform (End A) and seabed (End B) (4 Line; Current $1 \mathrm{~m} / \mathrm{s}$ )

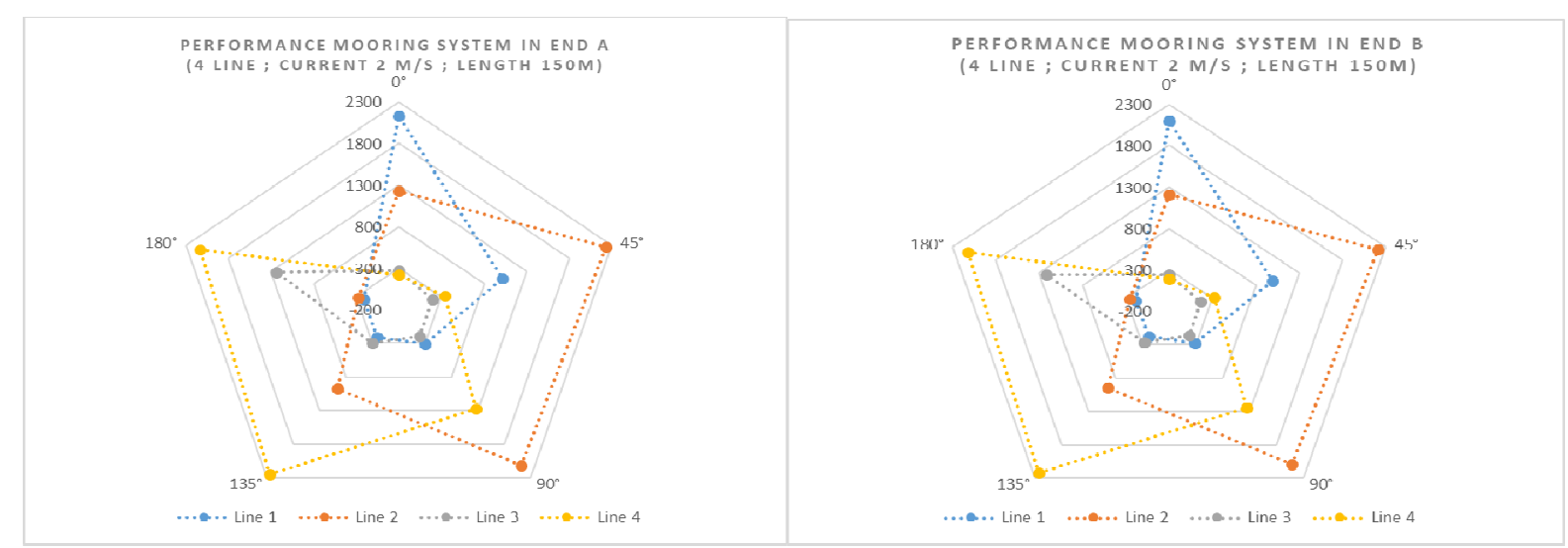

Figure 6. Distribution of mooring chain tension on the platform (End A) and seabed (End B) (4 Line; Current $2 \mathrm{~m} / \mathrm{s}$ ) 
International Journal of Marine Engineering Innovation and Research, Vol. 3(4), Mar. 2019. 118-127 (pISSN: 2541-5972, eISSN: 2548-1479)

TABLE 8 .

Distribution of Mooring Chain Tension on the Platform (End A) And SEABed (End B) (3 LINE; CURRENT $1 \mathrm{M} / \mathrm{S}$ )

\begin{tabular}{|c|c|c|c|c|c|}
\hline \multirow{2}{*}{ Line } & \multicolumn{5}{|c|}{ Degree } \\
\hline & $0^{\circ}$ & $45^{\circ}$ & $90^{\circ}$ & $135^{\circ}$ & $180^{\circ}$ \\
\hline 1 & 2607,664 & 2122,257 & 454,7516 & 52,46166 & 52,64523 \\
\hline 2 & 45,80473 & 43,75556 & 48,48079 & 1275,759 & 2218,79 \\
\hline 3 & 1153,375 & 2467,936 & 2401,935 & 2130,35 & 992,9244 \\
\hline \multicolumn{6}{|c|}{ End $B-$ unit in $k N$} \\
\hline \multirow{2}{*}{ Line } & \multicolumn{5}{|c|}{ Degree } \\
\hline & 0 & 45 & 90 & 135 & 180 \\
\hline 1 & 2595,764 & 2109,817 & 441,3434 & 38,72026 & 37,65457 \\
\hline 2 & 32,89491 & 30,25311 & 34,74776 & 1262,434 & 2205,955 \\
\hline 3 & 1139,633 & 2454,706 & 2389,32 & 2118,441 & 979,9707 \\
\hline
\end{tabular}

TABLE 9.

Distribution of Mooring Chain Tension on the Platform (End A) And SEABed (End B) (4 LINE; CURRENT $1 \mathrm{M} / \mathrm{S}$ )

\begin{tabular}{|c|c|c|c|c|c|}
\hline \multirow{2}{*}{ Line } & \multicolumn{5}{|c|}{ Degree } \\
\hline & $0^{\circ}$ & $45^{\circ}$ & $90^{\circ}$ & $135^{\circ}$ & $180^{\circ}$ \\
\hline 1 & 875,2696 & 670,2718 & 473,5734 & 388,2977 & 395,2507 \\
\hline 2 & 645,0016 & 846,2633 & 819,652 & 598,4065 & 407,9785 \\
\hline 3 & 403,9634 & 335,9556 & 341,1243 & 429,3618 & 650,0886 \\
\hline 4 & 399,2013 & 500,8082 & 716,5459 & 901,4253 & 881,0379 \\
\hline \multicolumn{6}{|c|}{ End $B-$ unit in $k N$} \\
\hline \multirow{2}{*}{ Line } & \multicolumn{5}{|c|}{ Degree } \\
\hline & 0 & 45 & 90 & 135 & 180 \\
\hline 1 & 852,0159 & 646,853 & 449,8798 & 364,4584 & 371,1584 \\
\hline 2 & 621,4544 & 822,9672 & 796,3678 & 575,0278 & 384,4012 \\
\hline 3 & 380,2788 & 312,1684 & 317,0563 & 405,5254 & 626,4129 \\
\hline 4 & 376,8116 & 478,6589 & 698,3657 & 879,7619 & 859,4544 \\
\hline
\end{tabular}

TABLE 10.

Distribution of Mooring Chain Tension on the Platform (End A) And SEABed (End B) (4 LiNE; CURRENT $2 \mathrm{M} / \mathrm{S}$ )

\begin{tabular}{|c|c|c|c|c|c|}
\hline \multirow{2}{*}{ Line } & \multicolumn{5}{|c|}{ Degree } \\
\hline & $0^{\circ}$ & $45^{\circ}$ & $90^{\circ}$ & $135^{\circ}$ & $180^{\circ}$ \\
\hline 1 & 2125,02 & 1011,756 & 304,147 & 204,9567 & 211,0848 \\
\hline 2 & 1229,864 & 2227,835 & 2114,374 & 967,2952 & 272,9746 \\
\hline 3 & 266,8364 & 193,0015 & 198,5888 & 297,7371 & 1234,895 \\
\hline 4 & 213,9925 & 341,5766 & 1270,165 & 2245,822 & 2136,233 \\
\hline \multicolumn{6}{|c|}{ End $B-$ unit in $k N$} \\
\hline \multirow{2}{*}{ Line } & \multicolumn{5}{|c|}{ Degree } \\
\hline & 0 & 45 & 90 & 135 & 180 \\
\hline 1 & 2102,882 & 988,9337 & 280,4673 & 180,7713 & 186,2123 \\
\hline 2 & 1206,366 & 2205,209 & 2092,061 & 944,4655 & 249,4123 \\
\hline 3 & 243,149 & 168,9623 & 173,8319 & 273,5104 & 1211,271 \\
\hline 4 & 190,5627 & 318,9337 & 1248,406 & 2224,896 & 2115,788 \\
\hline
\end{tabular}




\section{CONCLUSION}

Based on the simulation and discussion, the conclusions obtained are as follows:

1. The cylindrical hull platform behaviour moves at 6 degrees of freedom in each motion and direction, the largest Surge motion is $4.2 \mathrm{~m} / \mathrm{m}$ in the direction of 90 degrees load, the largest Sway motion has a value of $1.2 \mathrm{~m} / \mathrm{m}$ in the direction of 0 degrees, the largest Heave motion has a value of $0.65 \mathrm{~m} / \mathrm{m}$ in the direction of 180 degrees, the largest roll has a value of $2.4 \mathrm{deg} / \mathrm{s}$ in the direction of 0 degrees, the largest Pitch motion has a value of $4.8 \mathrm{deg} / \mathrm{s}$ in the direction of 180 degrees, and the largest Yaw motion has a value of $3.6 \mathrm{deg} / \mathrm{s}$ in the direction of 0 degrees.

2. Ocean Current Energy (OCE) with 4 mooring lines has lowest tension and safer than used 3 mooring lines.

3. The safety factor value of the selected chain is 1.73 , it is meet the minimum criteria required from the API RP 2SK standard of 1.67.

\section{REFERENCES}

[1] I. S. Arief, T. B. Musriyadi, and D. R. Aldara, "Design and Simulation of Axial Turbine for Ocean Thermal Energy Conversion (OTEC)," Int. J. Mar. Eng. Innov. Res., vol. 3, no. $1,2018$.
[2] K.E.S.D.M., Indonesia, Handbook Energy and Energy Statistics ESDM. Jakarta: Pusdatin ESDM, 2016.

[3] S. P. Neill et al., "The wave and tidal resource of Scotland," Renew. Energy, vol. 114, pp. 3-17, Dec. 2017.

[4] R. Swift, Assessment of performance of tidal energy conversion systems: marine renewable energy guides. Orkney: European Marine Energy Centre : Dept. for Business Enterprise \& Regulatory Reform, 2009.

[5] A. Baidowi and I. S. Arief, "The Hull Strength of Marine Current Turbine Platform," Int. J. Mar. Eng. Innov. Res., vol. 2, no. 3, 2018.

[6] DNV, Environmental Conditions and Environmental Loads. Oslo: DNV GL, 2010.

[7] G. Rajgor, "Asian interest in tidal grows," Renew. Energy Focus, vol. 19-20, pp. 124-128, Jun. 2017.

[8] M. T. Silva, "Ocean Surface Wave Spectrum," 2015.

[9] M. Wu, "Dynamic analysis of a subsea module during splashzone transit," Master's Thesis, Institutt for marin teknikk, 2013.

[10] H. Anindyasarathi, "Analisis Pengaruh Peninggian Platform Akibat Subsidence dengan Pendekatan Statis Berbasis Resiko," Institut Teknologi Sepuluh Nopember, 2013.

[11] M. Karimirad, "Wave- And Wind-Induced Dynamic Response Of A Spar-Type Offshore Wind Turbine," QUB Belf., 2011.

[12] E. B. Djatmiko, Perilaku dan Operabilitas Bangunan Laut di Atas Gelombang Acak. Surabaya: ITS Press, 2012.

[13] F. A. Fitria, "Studi Pengaruh Penambahan Clump Buoy Pada System Mooring Platform Pltal Laut Dalam," Int. J. Mar. Eng. Innov. Res., no. Renewable Energy, 2018.

[14] L. C. Pramana, "Studi Kekuatan Struktur Lambung Pembangkit Listrik Tenaga Arus Laut (Plt Arus Laut Platform Patamaran)," Int. J. Mar. Eng. Innov. Res., 2018.

[15] API, Design and Analysis of Stationkeeping System for Floating Structure. New York: American Petroleum Institute (API), 2005. 